zeszyt $153,2018,105-131$

doi: $10.4467 / 20833113$ PG.18.006.8481

Instytut Geografii i Gospodarki Przestrzennej UJ

Wydawnictwo Uniwersytetu Jagiellońskiego

\title{
ANTHROPOGENIC DENUDATION IN MINING AREAS ON THE EXAMPLE OF THE WAŁBRZYCH COAL MINING AREA (SUDETES, POLAND)
}

\author{
Jan Wójcik
}

\section{Denudacja antropogeniczna na obszarze górniczym na przykładzie Zagłębia Wałbrzyskiego (Sudety, Polska)}

\begin{abstract}
In the $20^{\text {th }}$ century Wałbrzych and its surroundings was the most prominent area of coal mining in the Sudetes. Nevertheless, in 1997 the mines were closed. An intensive anthropogenic geomorphic cycle commenced there in 1865 and lasted for 130 years. The biggest transformations in landforms occurred in two basins: Wałbrzych and Kuźnice, where a complex of anthropogenic forms was created from dumps and settling ponds, as well as subsidence depression. Among the dominant geomorphic processes related to anthropopressure were anthropogenic aggradation and anthropogenic denudation. Those processes resulted in raising and lowering of the land surface. Their intensity was diverse both in time and space. The average pace of anthropogenic aggradation in the years 1865-1996 amounted to 328 $\mathrm{mm} /$ year and was higher in the years 1945-1996 (439 mm/year) than during the period from 1865 to 1944 ( $255 \mathrm{~mm} /$ year). In both basins: Wałbrzych and Kuźnice, there was an increase in the intensity of this process in the years 1945-1996 when compared to the period of 1865-1944. The pace of anthropogenic denudation in the Wałbrzych coal mining area was considerably lower than the intensity of anthropogenic aggradation. During the research period, the land surface lowered, on average, by $66 \mathrm{~mm} / \mathrm{year}$, whereas the pace of the process decreased from $75 \mathrm{~mm} /$ year in the years $1865-1944$ to $57 \mathrm{~mm} /$ year in the period 1945-1996. A considerably higher intensity of anthropogenic denudation was noted the Wałbrzych Basin (96 mm/year) than in the Kuźnice Basin (36 mm/year). It was determined that the anthropogenic denudation balance in the in the Wałbrzych coal mining area in the years 1865-1996 was positive $(+262 \mathrm{~mm} /$ year). When comparing the scale of anthropogenic aggradation and denudation in several coal mining areas (Wałbrzych, Upper Silesia, Ostrava-Karvina and Ruhr), it needs
\end{abstract}


to be emphasized that in the research area the intensity of those processes in the period 1865-1996 was similar and, at times, higher than in the other areas, which results from the preference of cumulating of gangue on spoil tips as the cheapest way of its disposal, as well as from the dominance of caving coal extraction.

Keywords: Wałbrzych coal mining area, coal mining, anthropogenic forms, anthropogenic denudation, anthropogenic aggradation

Zarys treści: W XX w. Zagłębie Wałbrzyskie było największym obszarem wydobycia węgla kamiennego w Sudetach. W 1997 r. kopalnie zamknięto. Intensywny antropogeniczny cykl rzeźbotwórczy rozpoczął się tu w 1865 r. i trwał 130 lat. Największe przeobrażenia w ukształtowaniu powierzchni terenu wystąpiły w dwóch kotlinach: Wałbrzyskiej i Kuźnickiej. Powstał kompleks rzeźby antropogenicznej utworzony z hałd i osadników kopalnianych oraz niecek z osiadania. Dominującymi procesami rzeźbotwórczymi w związku z antropopresją były agradacja antropogeniczna i denudacja antropogeniczna. Procesy te przyczyniły się do podwyższenia i obniżenia powierzchni terenu. Ich natężenie było zróżnicowane w czasie i w przestrzeni. Średnie tempo agradacji antropogenicznej w latach 1865-1996 wynosiło 328 mm/r. i było większe w latach 1945-1996 (439 mm/r.) niż w okresie 1865-1944 (255 mm/r.). W obu kotlinach: Wałbrzyskiej i Kuźnickiej wystąpił wyraźny wzrost natężenia tego procesu w latach 1945-1996 w porównaniu z okresem 1865-1944. Tempo denudacji antropogenicznej w Zagłębiu Wałbrzyskim było znacznie mniejsze od natężenia agradacji antropogenicznej. W rozpatrywanym okresie powierzchnia terenów górniczych obniżała się średnio $66 \mathrm{~mm} / \mathrm{r}$., przy czym tempo tego procesu spadło z $75 \mathrm{~mm} / \mathrm{r}$. w latach 1865-1944 do $57 \mathrm{~mm} / \mathrm{r}$. w okresie 1945-1996. Znacznie większe natężenie denudacji antropogenicznej wystąpiło w Kotlinie Wałbrzyskiej ( $96 \mathrm{~mm} / \mathrm{r}$.) niż w Kotlinie Kuźnickiej (36 mm/r.). Ustalono, że bilans denudacji antropogenicznej w Zagłębiu Wałbrzyskim w latach 1865-1996 był dodatni (+262 mm/r.). Porównując rozmiary agradacji antropogenicznej i denudacji antropogenicznej w Zagłębiu Wałbrzyskim i innych zagłębiach węgla kamiennego (Górnośląskim, Ostrawsko-Karwińskim i Ruhry) należy podkreślić, że w badanym obszarze natężenie tych procesów w latach 1865-1996 było podobne, a czasem większe niż w innych zagłębiach. Wiąże się to z preferowaniem gromadzenia skał płonnych na hałdach, jako najtańszego sposobu ich unieszkodliwiania oraz z przewagą wydobycia węgla metodą na zawał.

Stowa kluczowe: Zagłębie Wałbrzyskie, górnictwo węglowe, formy antropogeniczne (hałdy, osadniki, niecki z osiadania, denudacja antropogeniczna, agradacja antropogeniczna)

\section{Introduction}

Coal extraction in the Sudetes commenced as early as in the 15th century (Pflug 1908; Jaros 1975). However, the intensive development of coal mining did not take place until the second half of 19 th century. The biggest area of coal mining at that time was the Wałbrzych coal mining area, which is also the place of the biggest relief transformations resulting from coal mining in the Sudetes (Jońca, Kacperkiewicz 1986; Wójcik 1993, 2011, 2013). The Wałbrzych coal mines were closed in 1997. 
In the years 1865-1996 the exploitation of coal in the Wałbrzych coal mining area resulted in transferring of considerable amount of rocks located in the surface layer of lithosphere and on the surface of the ground. This substantially influenced the denudation balance of the area. The loss of rock mass resulting from mining exploitation is a part of anthropogenic denudation, while its increase on the surface of the ground should be considered as anthropogenic aggradation (Zapletal 1968; Mannion 1997; Dulias 2016). The comparison of the pace of anthropogenic denudation with natural denudation in numerous mining regions in the World indicates the dominance of the first of the processes, which was noticed by the precursors of anthropogenic geomorphology, among others: Marsch (1864), Fischer (1915) and Sherlock (1923). Anthropogenic denudation is considered as one of the essential contemporary geomorphological processes and its research is among the most crucial problems of geomorphology (Douglas, Lawson 2001; Wilkinson, Mc Elroy 2007).

\section{Research goals}

The aim of the paper is to determine the scale of anthropogenic aggradation and anthropogenic denudation as significant geomorphological factors in the Wałbrzych coal mining area, as well as the spatial diversification of intensity of those processes in relation to the distinctive mountainous character of the relief. It needs to be emphasized that no research concerning anthropogenic denudation was conducted in the aforementioned area beforehand. What is more, the author compared the intensity of those processes with the size of aggradation and natural denudation in the research area. The research results presented in the article concern the last 130 years of development of Wałbrzych coal mining, as for such a period it was possible to determine the scale of coal extraction, as well as gangue accumulated annually and vertical sizes of rock mass subsiding resulting from coal exploitation in the Wałbrzych coal mining area. That data was key to determine the scale of anthropogenic aggradation and anthropogenic denudation. Another important goal of the paper was to conduct comparison studies of the pace of aforementioned processes in the Wałbrzych coal mining area and other mining areas both in Poland and Europe.

\section{Sources and methods}

The article includes various published sources, i.a. department statistics of coal industry in Poland and statistical yearbooks of coal mines, as well as unpublished materials from numerous institutions (mines, offices, archives), including more of less detailed information and statistical data concerning coal extraction and gangue 
management, as well as the extent and results of anthropogenic transformations of relief. It needs to be emphasized that part of those materials was either lost or destroyed during the shutdown of coal mines in Wałbrzych. The author also used the archival and contemporary cartographical materials at the scale of 1:10000 and 1:25000 and schemes of former mining sites of Wałbrzych mines at the scales of 1:1000 and 1:5000. Another valuable source of information concerning the relief transformation in the years 1884-1939 are topographic maps from the Messtischblätter series at the scale of 1:25000 (sheets: Waldenburg [In Schlesien] [1886] and Waldenburg [In Niederschlesien] [1930, 1939]). The aforementioned maps are currently considered as fully cartometric sources of information concerning, among others, the relief (Graf et al. 2008; Dulias 2013).

The scale of anthropogenic denudation was calculated using three methods. The first was the method introduced by $\dot{Z}$ muda (1973) and modified by Dulias (2013) and it assumed the calculation of anthropogenic denudation based on the amount of extracted coal and gangue. Assuming, after Dulias (2013), that 1 ton of coal has a volume of $0.74 \mathrm{~m}^{3}$ and 1 ton of gangue $0.38 \mathrm{~m}^{3}$, and, after Jońca, Kacperkiewicz (1986) and the author (Wójcik 2013), that for every ton of coal extracted in the Wałbrzych coal mining area there was 1.6 ton of gangue $\left(0.61 \mathrm{~m}^{3}\right)$, the volume of rock mass extracted in the years 1865-1996 was calculated (the volume of underground mining excavations). It was estimated that $60 \%$ of coal was excavated using caving, while $40 \%$ using backfill method. The obtained values were multiplied by subsidence ratios; in case of caving 0.7, while in case of backfill 0.15 (as in Borecki 1980). Next, the values were divided by the size of the mining area and the years of mining activity. The value of anthropogenic denudation calculated in this way determined the pace of lowering of the level of terrain in mm/year. Another way to determine the intensity of anthropogenic denudation was using of results of geodetic measurements of ground subsiding carried out in the years 1912-1996 in 31 locations within the research area. That data constitutes the most reliable information concerning the subsiding of terrain in the studied area.

The scale of anthropogenic denudation was also calculated based on the morphometric analysis of topographic maps presenting the research area at the scale of 1:25000 mapped out in 1884, 1930 and 1939, and at the scale of 1:10000 from 1976 and 1996. Next, digital models of the relief were created. Cartometric analyses enabled to obtain new data concerning the subsiding of the terrain in particular periods. The results of measurements were compared with data concerning the terrain subsiding which were obtained using different methods.

The intensity of anthropogenic aggradation was calculated based on the prior establishments of the author concerning the amount of gangue and other mining waste stored on dumps and settling ponds in the years 1865-1996, referring to the sizes of mining areas and periods of mining activity (Wójcik 1993, 1996, 2011). 
The research period was divided into two sub periods: 1865-1944 and 1945-1996, which results from a bigger number and better access to source materials for the second of the aforementioned periods, as well as the changing political and economical situation of the Wałbrzych coal mining area Basin during those years.

\section{The location of the research area}

The Wałbrzych coal mining area is located in the Sudetes and covers the area of $95 \mathrm{~km}^{2}$ (Fig. 1). Coal was mined there in the Wałbrzych and Kuźnice basins with the area of $38 \mathrm{~km}^{2}$. In 1997 the mines were closed. Currently the Wałbrzych coal mining area is the area with the most substantial anthropogenic transformations of the relief in the Lower Silesia Coal Mining Area (Wójcik 2011, 2013).

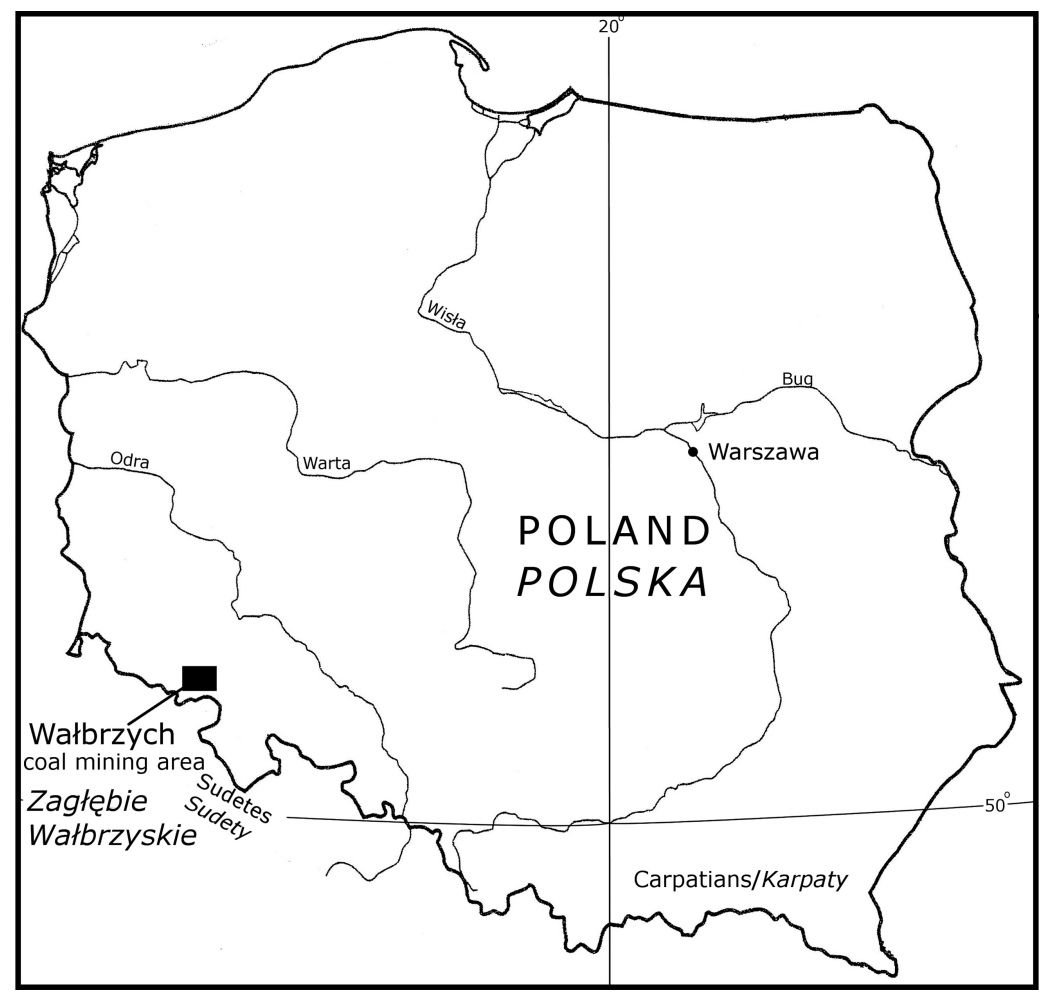

Fig. 1. Investigated area

Ryc. 1. Teren badań 


\section{Selected publications}

The term denudation was introduced to the Earth science in 1847 by Lyell (after Gregory 1911). Since that time, the term was variously defined (Tricart 1953; Spencer 1983; England, Molnar 1990; Dulias 2013). The definitions mostly referred to the character of the processes distinguishing mechanical and chemical denudation (Corbel 1959, 1968; Tricart 1960; Pulina 1974; Goudie 1995; Sheen 2000; Walling 2006).

The first attempts of assessment and systematization of the results of anthropopression in the relief in the geographical literature were made by, among others: Marsch (1864), Fischer (1915) and Sherlock (1923). What is more, the attempts of quantitative analysis of results of anthropopressure were made as early as at the beginning of the 20th century. The comparative analyses of dynamics of natural processes and anthropopressure indicated a distinct domination of the latter. It was assumed that humans became an important geomorphological factor and the results of their activity often surpassed the results of natural geomorphological processes (Goudie, Viles 1997; Hooke 1999; Price et al. 2011; Dulias 2013). In order to distinguish natural and human induced denudation the term anthropogenic denudation was introduced (Dylik 1958; Tricart 1960; Zapletal 1969; Demek 1973; Wilkinson, Mc Erloy 2007).

In the Polish geographical literature the issue of anthropogenic denudation is related mainly to the influence of agriculture on the slopes and their development (Dylik 1954, 1958; Jahn 1968; Lach 1984; Sinkiewicz 1998; Smolska 2005). Among the results of those processes one can mention the accumulation of sediments in river valleys, also known as anthropogenic aggradation. Certain researchers give this term a wider meaning, indicating that it also encompasses overbuilding of terrain related to various human activities (Zapletal 1968; Demek 1973; Klimaszewski 1978).

The term anthropogenic denudation was used for the first time in reference to mining areas in Poland by Jania (1983). The aforementioned researcher, as well as Podgórski (2001), claims that anthropogenic forms are closely related to the geological structure of the area of mineral resources excavation. Therefore, the spatial distribution of anthropogenic denudation refers to geological composition. Among the researchers who studied the scale of that process in Polish mining areas we can list: Żmuda (1973), Szczypek, Trembaczowski (1987), Dulias (2011, 2013), Kupka et al. (2005,), as well as Solarski, Pradela (2010).

When referring to the Wałbrzych coal mining area it needs to be emphasized that, until now, no research concerning the influence of anthropogenic denudation on relief has been conducted, and the present article is the first attempt of assessment of transformations in the terrain caused by that process. 


\section{Characteristic features and extents of mining transformations in the Wałbrzych Basin relief}

The time from 1853 to 1880 was a breakthrough period in the development of coal mining in the Wałbrzych coal mining area. In 1863 railway was built in Wałbrzych connecting it with other centres, what is more, that year also marks the beginning of use of new technologies in coal exploitation which led to a sixfold increase in extraction of this raw material during the aforementioned period (Ohle 1927; Luksa 1959; Wójcik 1993). That time was also the beginning of a period of intensive transformation of the terrain by mining, which lasted until closing of the mines in 1997 (Wójcik 2011, 2013). That period, referred to by the author as anthropogenic geomorphological cycle, is the time of emerging of complex of anthropogenic relief with numerous dumps, settling ponds and subsidence depressions. The relief is a result of simultaneous destructive and developing human activity on the ground surface. Dumps and settling ponds transformed in total 379 ha of ground, while their volume amounted to 92 million $\mathrm{m}^{3}$. Subsidence depressions are the biggest anthropogenic forms in the research area, as they are up to $2 \mathrm{~km}$ long and $1 \mathrm{~km}$ wide, however they are considerably shallow (up to $17.9 \mathrm{~m}$ ) (Czocher et al. 1978; Rejman 1982; Pinińska 1993; Wójcik 2011, 2013). The forms altogether occupy the area of $36 \mathrm{~km}^{2}$, from which $29 \mathrm{~km}^{2}$ is located in the Wałbrzych Basin and $7 \mathrm{~km}^{2}$ in the Kuźnice Basin. In the first of the aforementioned areas emerged two broad depressions with a depth of 17.9 and $10.9 \mathrm{~m}$ separated by a zone of lesser relief deformations. The distorted relief is $6 \mathrm{~km}$ long (N-S) and $5 \mathrm{~km}$ wide (W-E). In the Kuźnice Basin subsidence depressions cover a smaller area (NW-SE: $4 \mathrm{~km}, \mathrm{NE}-\mathrm{SW}: 1 \mathrm{~km}$ ) and are shallower (3.3 m) (Wójcik 2011, 2013).

\section{Anthropogenic aggradation in the Wałbrzych Basin}

One of characteristic processes of anthropopressure in mining areas are movements of substantial amounts of rock body both within the rock mass and on the ground surface. With reference to the studied area, the precise data concerning anthropogenic movements of rock body could be determined only for the period 1865-1996, as prior to that period, either the measurements had not been conducted, or the data had been lost (Wójcik 1993, 2011). Therefore, the quantitative analysis of the scale and pace of anthropogenic aggradation and anthropogenic denudation in the Wałbrzych coal mining area, in the light of mechanical relocation of rock body, was possible only for the last 130 years of mining development. It needs to be emphasized that those processes were changing both in time and space in relation to the changes in the areas of coal excavation. 
It was determined that the beginning of the anthropogenic aggradation process in the research area, whose results are visible until today in the relief, commenced in 1865; it was the time when the oldest dump in the Wałbrzych coal mining area was created (Wójcik 2011). In the years 1865-1996, 39 dumps of various sizes covered the area of $3.05 \mathrm{~km}^{2}$, where 217.6 million tons of various rock waste was accumulated with the total volume of 82.7 million $\mathrm{m}^{3}$. Moreover, coal mining contributed to the elimination of depressions on the area amounting to $1.21 \mathrm{~km}^{2}$. It is estimated that as much as 10.8 million $\mathrm{m}^{3}$ of mining waste was accumulated there. During the research period dumps and anthropogenic surfaces covered the area of $4.26 \mathrm{~km}^{2}$ of grounds and the total volume of waste assembled there amounted to 93.5 million $\mathrm{m}^{3}$. It was calculated that the average pace of growth of dumps and levelled land, in the years 1865-1996, at the scale of the entire Wałbrzych coal mining area, amounted to 32.5 thousand $\mathrm{m}^{2}$. During the period of 1865-1944, the increase in the size of the area was slower (17.6 thousand $\mathrm{m}^{2} / \mathrm{year}$ ) than in the period from 1945 to 1996 (55.2 thousand $\mathrm{m}^{2} /$ year). Considering two areas of coal mining: Wałbrzych and Kuźnice basins, it was determined that in the first of the aforementioned basins the average annual pace of increase in the area of dumps and levelled land was sixfold faster than in the other area (28.2 thousand $\mathrm{m}^{2}$ and 4.4 thousand $\mathrm{m}^{2}$ ). Also in the years 1945-1996, the increase in the size of the area of the analyzed basins progressed faster than during the period 1865-1944 (48.3 thousand $\mathrm{m}^{2} /$ year and 6.9 thousand $\mathrm{m}^{2} /$ year and 14.9 thousand $\mathrm{m}^{2} /$ year and 2.7 thousand $\mathrm{m}^{2} /$ year). To sum up, it was determined that the dynamics of development of anthropogenic areas in the Wałbrzych coal mining area was diverse both in time and space. Their development progressed more dynamically in the years 1945-1996 than during the period 1865-1944. What is more, the dynamics of those changes in the aforementioned periods was higher in the Wałbrzych Basin than in the Kuźnice Basin.

Considering the combined volume of mining waste accumulated on the surface of the researched area in the years 1865-1996, and during the periods: 1865-1944 and 1945-1996, as well as the changing surface of mining areas, it was possible to determine the average pace of anthropogenic aggradation per year. During the research period the intensity of anthropogenic aggradation in the Wałbrzych coal mining area amounted to $328 \mathrm{~mm} /$ year. In the years 1865-1944 the pace of the process was considerably slower (255 mm/year) than after 1945 (439 mm) (Tab. 1). This phenomenon was closely related to the varying amount of waste accumulated on dumps. During the period from 1865 to 1944 the amount of mining waste transported to dumps was considerably lower than in the years 1945-1996 (0.35 million $\mathrm{m}^{3}$ and 1.26 million $\mathrm{m}^{3}$ ), which was conditioned by the access to deep coal beds after 1945 and drilling of "Copernicus" shaft in order to concentrate coal extraction in the Wałbrzych coal mining area. What is more, storage of waste on dumps was 
preferred as the cheapest way of their disposal. Shrinking of available waste storage areas led to a quick development of dumps. The pace of growth of volume of those forms was quicker than that of their area, which resulted in a considerable increase of height difference (up to $150 \mathrm{~m}$ ) and relief dynamics (Wójcik 2011). There also was a significant differentiation in the intensity of anthropogenic aggradation. In the Kuźnice Basin the increase in the number of anthropogenic forms progressed quicker than in the Wałbrzych Basin (455 mm/year and $307 \mathrm{~mm} / \mathrm{year}$ ). What is more, during the analyzed periods (1865-1944 and 1945-1996) the average annual pace of anthropogenic aggradation was faster in the Kuźnice Basin than in the Wałbrzych Basin (361 $\mathrm{mm}$ and $568 \mathrm{~mm}$ as well as $416 \mathrm{~mm}$ and $236 \mathrm{~mm}$ ). In both basins the average annual intensity of this process was considerably higher in the second than in the first of the aforementioned periods (Tab. 1).

While analyzing selected dumps and periods of their use, it was determined that the differentiation of intensity of anthropogenic aggradation was considerable (Fig. 2). It was determined that in the Kuźnice Basin the scale of this process varied from $315 \mathrm{~mm} /$ year to $914 \mathrm{~mm} / \mathrm{year}$, while in the Wałbrzych Basin the differentiation was higher, as it amounted to $217-1818 \mathrm{~mm} / \mathrm{year}$. One of the results of permanent anthropogenic aggradation in the years 1865-1996 is the occurrence of significant changes in the relief of the studied basins (Fig. 3 and 4). Dumps ranging to $105 \mathrm{~m}$,

Table 1. The development of area and volume of dumps and areas levelled by mining and intensity of anthropogenic aggradation in the Wałbrzych Basin in between 1865-1996

Tab. 1. Rozwój powierzchni i objętości hałd wraz z powierzchniami antropogenicznymi oraz natężenie agradacji antropogenicznej w Zagłębiu Wałbrzyskim w latach 1865-1996

\begin{tabular}{|c|c|c|c|c|c|c|c|}
\hline \multirow{3}{*}{\multicolumn{2}{|c|}{$\begin{array}{c}\text { Specification } \\
\text { Wyszczególnienie }\end{array}$}} & \multirow{2}{*}{\multicolumn{2}{|c|}{$\begin{array}{c}\text { Wałbrzych Basin } \\
\text { Kotlina Wałbrzyska } \\
\text { Increase / Przyrost }\end{array}$}} & \multirow{2}{*}{\multicolumn{2}{|c|}{$\begin{array}{c}\text { Kuźnicka Basin } \\
\text { Kotlina Kuźnicka } \\
\text { Increase / Przyrost }\end{array}$}} & \multirow{2}{*}{\multicolumn{2}{|c|}{$\begin{array}{c}\text { Wałbrzychcoal mining area } \\
\text { Zagłębie Wałbrzyskie } \\
\text { Increase / Przyrost }\end{array}$}} \\
\hline & & & & & & & \\
\hline & & \multirow{2}{*}{$\begin{array}{l}\text { in total } \\
\text { ogółem } \\
3.69\end{array}$} & \multirow{2}{*}{$\begin{array}{c}A \text { (m²/year) } \\
A_{a}(\mathrm{~mm} / \text { year }) \\
28168\end{array}$} & \multirow{2}{*}{$\begin{array}{c}\begin{array}{c}\text { in total } \\
\text { ogółem }\end{array} \\
0.57\end{array}$} & \multirow{2}{*}{$\begin{array}{c}\mathrm{A}\left(\mathrm{m}^{2} / \text { year }\right) \\
\mathrm{A}_{\mathrm{a}}(\mathrm{mm} / \text { year }) \\
4,351\end{array}$} & \multirow{2}{*}{$\begin{array}{c}\begin{array}{c}\text { in total } \\
\text { ogółem }\end{array} \\
4,26\end{array}$} & \multirow{2}{*}{$\begin{array}{c}A \text { (m²/year) } \\
A_{a} \text { (mm/year) } \\
32,519\end{array}$} \\
\hline 6 & $\mathrm{~A}\left(\mathrm{~km}^{2}\right)$ & & & & & & \\
\hline (131 years / lat) & $V\left(m \ln m^{3}\right)$ & 76.3 & 158 & 17.2 & 230 & 93,5 & 168 \\
\hline \multirow{2}{*}{$\begin{array}{c}1865-1944 \\
\text { (79 years / lat) }\end{array}$} & $\mathrm{A}\left(\mathrm{km}^{2}\right)$ & 1.18 & 14,937 & 0.21 & 2,658 & 1,39 & 17,595 \\
\hline & $\mathrm{V}\left(\mathrm{mln} \mathrm{m}^{3}\right)$ & 22.0 & 236 & 6.0 & 361 & 28,0 & 255 \\
\hline \multirow{2}{*}{$\begin{array}{c}1945-1996 \\
\text { (52 years / lata) }\end{array}$} & $\mathrm{A}\left(\mathrm{km}^{2}\right)$ & 2.51 & 48,269 & 0.36 & 6,923 & 2,87 & 55,192 \\
\hline & $V\left(m \ln m^{3}\right)$ & 54.3 & 416 & 11.2 & 598 & 65,5 & 439 \\
\hline
\end{tabular}

Explanations: A: area (in $\mathrm{km}^{2}$ ); V: volume (in million $\left.\mathrm{m}^{3}\right)$; $\mathrm{A}_{\mathrm{a}}$ : anthropogenic aggradation (in mm/year). Objaśnienia: A: powierzchnia ( $\left.\mathrm{w} \mathrm{km}^{2}\right)$; V: objętość ( $\left.\mathrm{w} \mathrm{mln} \mathrm{m}^{3}\right)$; Aa agradacja antropogeniczna (w $\mathrm{mm} / \mathrm{r}$.). 


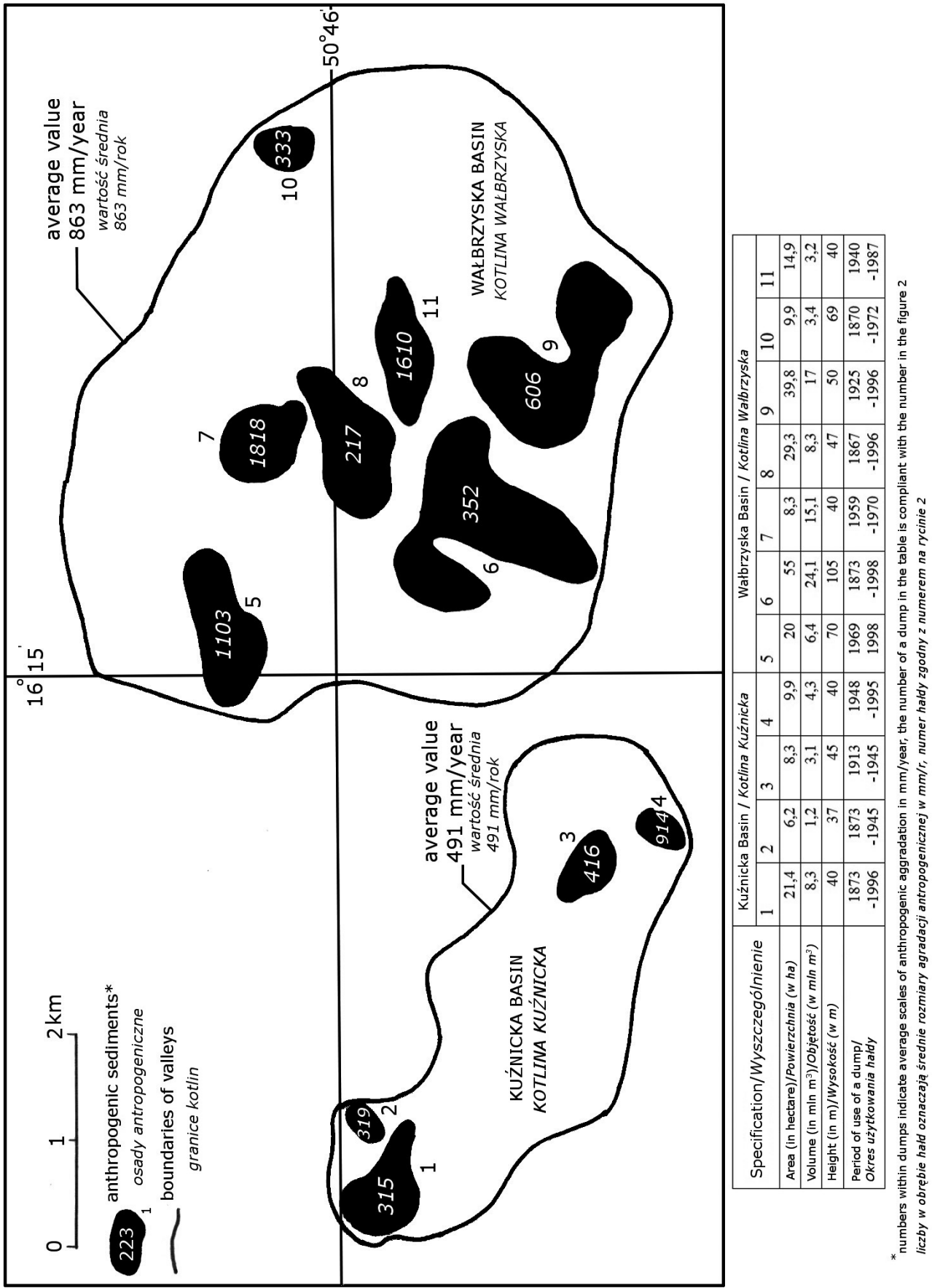




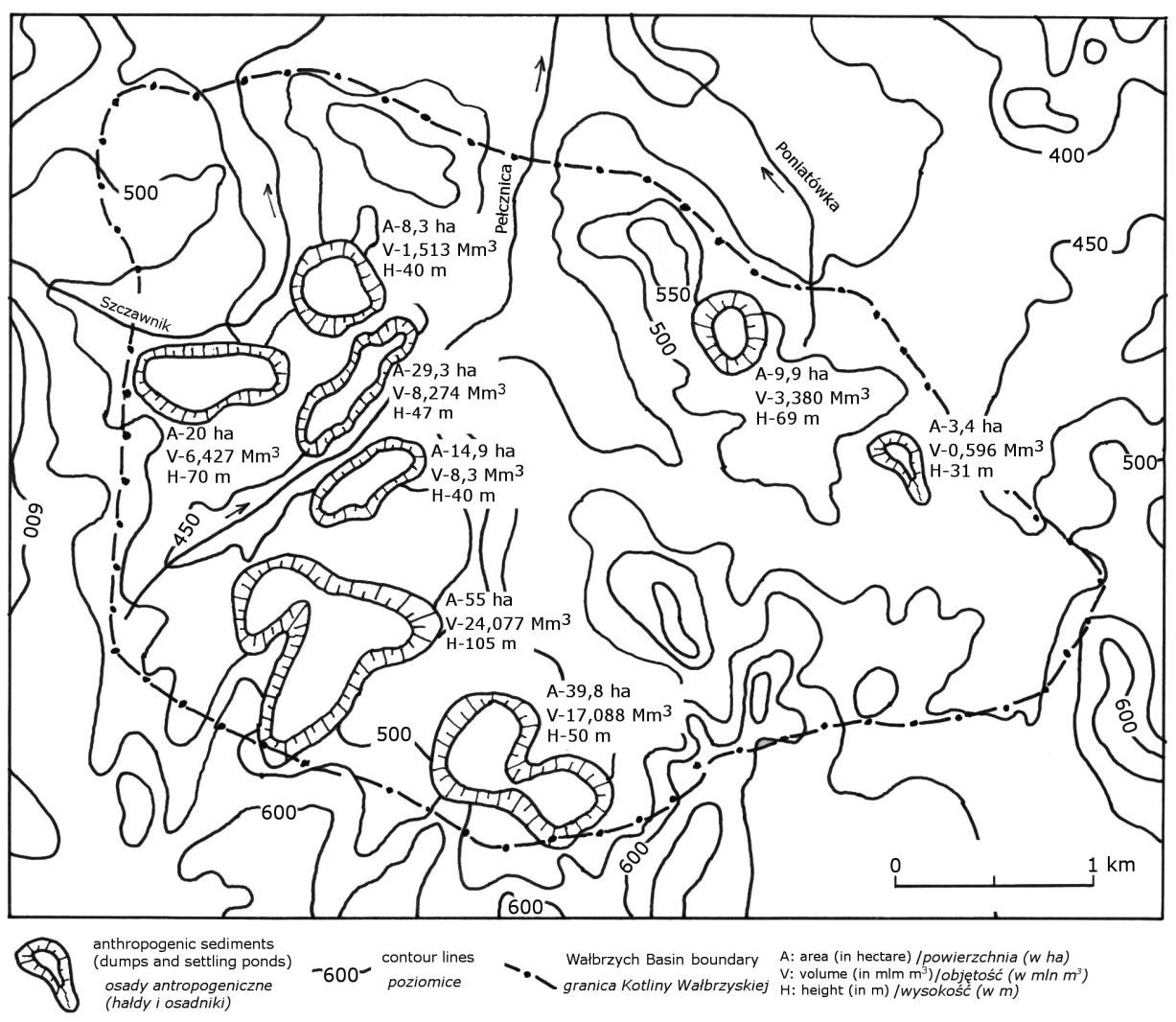

Fig. 3. Changes in the Wałbrzych Basin relief in between 1865-1996 caused by anthropogenic aggradation related to mining development

Ryc. 3. Zmiany w rzeźbie terenu Kotliny Wałbrzyskiej w latach 1865-1996 spowodowane agradacją antropogeniczną w związku z rozwojem górnictwa

$\leftarrow$

Fig. 2. Spatial differentiation of anthropogenic aggradation intensity for selected dumps and areas levelled by mining activity in the Wałbrzych Basin in between 1865-1996

Ryc. 2. Przestrzenne zróżnicowanie natężenia agradacji antropogenicznej dla wybranych hałd i powierzchni antropogenicznych związanych z działalnością górniczą Zagłębia Wałbrzyskiego w latach 1865-1996 
covering the space up to 50 ha and with volume amounting to 23.1 million $\mathrm{m}^{3}$ were created in numerous places, such as formerly flat surfaces and depressions of the basin bottom. The last 130 years of mining development in the research area was a period of considerable changes in relief dynamics, unprecedented in other parts of the Sudetes, as an example of which can serve the biggest dump in Wałbrzych, which has been transforming the flat bottom of the Wałbrzych Basin since 1873 (Photo 1).

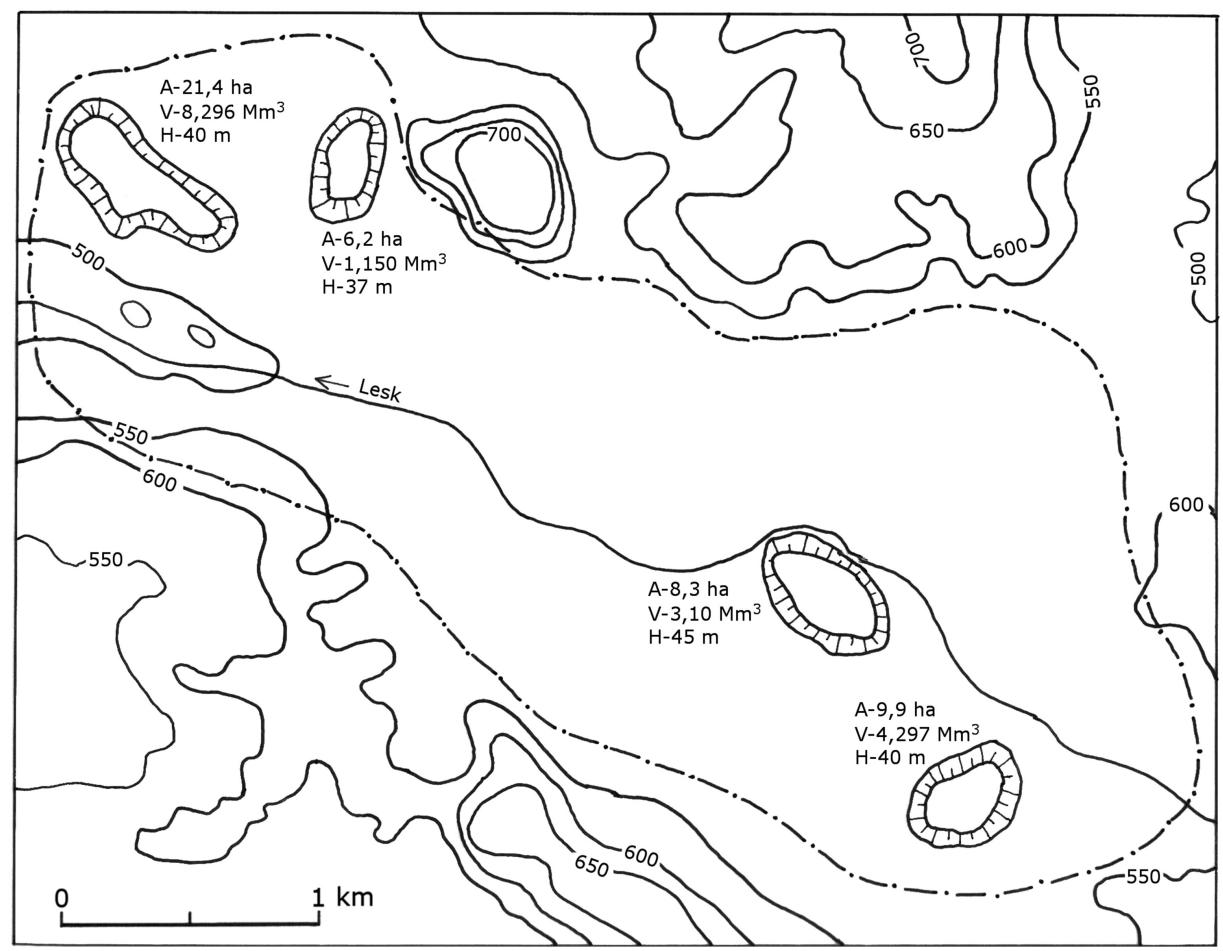

*legend is the same as in figure 3 /legenda jak na rycinie 3

Fig. 4. Changes in the Kuźnicka Basin relief in between 1865-1996 caused by anthropogenic aggradation related to mining development

Ryc. 4. Zmiany w rzeźbie terenu Kotliny Kuźnickiej w latach 1865-1996 spowodowane agradacją antropogeniczną w związku z rozwojem górnictwa 


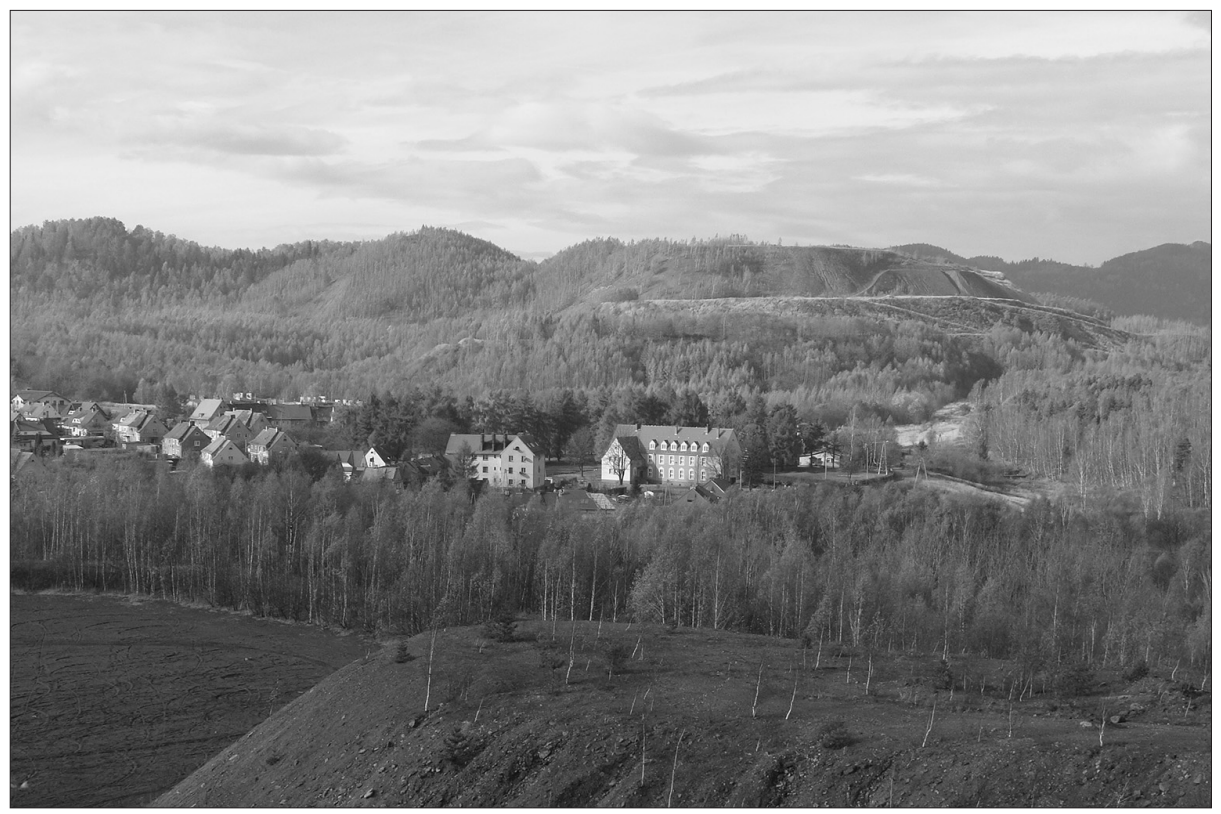

Photo 1. Anthropogenic inversion of relief in the Wałbrzych coal mining area. Landscape of the largest dump of the Wałbrzych coal mining area (50.0 hectares, $23.077 \mathrm{mln} \mathrm{m}^{3}, 105 \mathrm{~m}$ ), (photo by J. Wójcik)

Fot. 1. Antropogeniczna inwersja rzeźby w Zagłębiu Wałbrzyskim. Krajobraz największej hałdy Zagłębia Wałbrzyskiego (50,0 hektarów, 23,077 mln m³, 105 m), (fot. J. Wójcik)

\section{Anthropogenic denudation in the area of the Watbrzych Basin}

In the years 1865-1996, in the Wałbrzych coal mining area 388.7 million tons of coal was excavated from the rock mass, while in the period 1865-1944 272 million tons, and during the latter period 1945-1996 - 116.7 million tons (Tab. 2). Opening and exploitation of coal beds resulted in creation of 639.9 million tons of gangue, including 435.2 million tons until 1944 and 204.7 million tons in the years 1945-1996. Assuming, after $\dot{Z}$ muda (1973), that one ton of coal has a volume of $0.74 \mathrm{~m}^{3}$ and one tone of gangue $0.38 \mathrm{~m}^{3}$, and presupposing that in the Wałbrzych coal mining area for each tone of excavated coal there was 1.6 tone of gangue (Czocher et al. 1978; Wójcik 2011), the volume of voids created in the rock mass was calculated. During the research period, the excavations had the volume of 530.9 million $\mathrm{m}^{3}$; 366.7 million $\mathrm{m}^{3}$ was excavated until 1944 and during the period of 1945-1996 the 
Table 2. Hard coal and gangue extraction in the Wałbrzych Basin in the years 1865-1996 Tab. 2. Wydobycie węgla kamiennego i skał płonnych w Zagłębiu Wałbrzyskim w latach $1865-1996$

\begin{tabular}{|c|c|c|c|c|c|c|c|}
\hline \multirow{2}{*}{$\begin{array}{c}\text { Area influenced } \\
\text { by mining activity } \\
\left(\mathrm{km}^{2}\right) \\
\text { Powierzchnia pod } \\
\text { wpływem działalności } \\
\text { górniczej }\left(\mathrm{km}^{2}\right)\end{array}$} & \multirow[t]{2}{*}{$\begin{array}{c}\text { Period } \\
\text { Okres }\end{array}$} & \multicolumn{2}{|c|}{$\begin{array}{l}\text { Coal production } \\
\text { Wydobycie węgla }\end{array}$} & \multicolumn{2}{|c|}{$\begin{array}{l}\text { Amount of gangu } \\
\text { Ilość powstałych skał } \\
\text { płonnych }\end{array}$} & \multicolumn{2}{|c|}{$\begin{array}{c}\text { Gangue transported } \\
\text { to dumps } \\
\text { Skały płonne wywiezione } \\
\text { na hałdy }\end{array}$} \\
\hline & & \begin{tabular}{|c|} 
in million $\mathrm{t}$ \\
$\mathrm{w}$ mln $\mathrm{t}$ \\
\end{tabular} & \begin{tabular}{|c|} 
in million $\mathrm{m}^{3}$ \\
$\mathrm{w} \mathrm{mln} \mathrm{m}^{3}$
\end{tabular} & \begin{tabular}{|c|} 
in million $\mathrm{t}$ \\
$\mathrm{w} \mathrm{mln} \mathrm{t}$
\end{tabular} & \begin{tabular}{|c} 
in million $\mathrm{m}^{3}$ \\
$\mathrm{w} \mathrm{mln} \mathrm{m}^{3}$ \\
\end{tabular} & $\begin{array}{c}\text { in million } \mathrm{t} \\
\mathrm{w} \text { mln } \mathrm{t}\end{array}$ & \begin{tabular}{|c} 
in million $\mathrm{m}^{3}$ \\
w mln $\mathrm{m}^{3}$ \\
\end{tabular} \\
\hline \multirow{3}{*}{38} & $1865-1944$ & 272.0 & 201.3 & 435.2 & 165.4 & 48.7 & 18.5 \\
\hline & $1945-1996$ & 116.7 & 86.4 & 204.7 & 77.8 & 168.9 & 64.2 \\
\hline & $1865-1996$ & 388.7 & 287.7 & 639.9 & 243.2 & 217.6 & 82.7 \\
\hline
\end{tabular}

volume of voids increased by another 162.2 million $\mathrm{m}^{3}$ (Tab. 2). Based on various sources it was determined that $60 \%$ of coal excavation in the Wałbrzych Basin proceeded with using the caving method, while $40 \%$ using backfill method (Wójcik 1993, 2011). Referring to the research of Borecki (1980) and Dulias (2013) the land subsidence ratio with the use of caving method amounted to 0.7 , while with the backfill method to 0.15 . The volume of subsidence depressions was calculated while taking into consideration the volume of excavated coal and gangue, as well as the total area of terrain in the Wałbrzych coal mining area under which the coal was excavated and where land subsidence was determined using geodetic measurements. It was determined that in 1996 those forms had a volume of 215.8 million $\mathrm{m}^{3}$. In the Wałbrzych Basin subsidence depressions have a more considerable volume (192.1 million $\mathrm{m}^{3}$ ) than in the Kuźnice Basin (23.7 million $\mathrm{m}^{3}$ ) (Tab. 3). A significant dispersion of coal excavation in the Wałbrzych coal mining area in the second half of the 19th and at the beginning of the 20th century (Czocher et al. 1978; Wójcik 1993; Piątek 1995) led to the emergence of wide subsidence depressions. In 1944 in the Wałbrzych Basin those forms reached a volume of 133 million $\mathrm{m}^{3}$, while in the years 1945-1996 they gradually increased by 59 million $\mathrm{m}^{3}$, as a result of the emergence of new basins. During the aforementioned periods, the Kuźnice Basin experienced reverse proportions between the volume of subsidence depressions. Until 1944 their volume reached 10 million $\mathrm{m}^{3}$ and during the period 1945-1996 it increased by 13 million $\mathrm{m}^{3}$, which was a result of opening and exploitation of new coal seams in the Kuźnice Świdnickie region.

Considering the size of the area where rock mass subsidence was observed, as well as the allocated periods of coal exploitation and the volume of subsidence depressions it was possible to calculate the average size of terrain depression. In the years 1865-1996 the ground surface dipped by $6 \mathrm{~m}$, however, in the Wałbrzych 
Table 3. Anthropogenic denudation in the Wałbrzych Basin based on the coal and gangue extraction in the years 1865-1996

Tab. 3. Denudacja antropogeniczna w Zagłębiu Wałbrzyskim w świetle wydobycia węgla i skał płonnych w latach 1865-1996

\begin{tabular}{|c|c|c|c|}
\hline $\begin{array}{c}\text { Specification } \\
\text { Wyszczególnienie }\end{array}$ & $\begin{array}{l}\text { Wałbrzych Basin } \\
\text { Kotlina Wałbrzyska }\end{array}$ & $\begin{array}{l}\text { Kuźnicka Basin } \\
\text { Kotlina Kuźnicka }\end{array}$ & $\begin{array}{l}\text { Wałbrzych coal mining area } \\
\text { Zagłębie Wałbrzyskie }\end{array}$ \\
\hline $\begin{array}{l}\text { Mining area until } 1996 \text { (in km²) } \\
\text { Powierzchnia terenu górniczego } \\
\text { do } 1996 \mathrm{r} .\left(\mathrm{w} \mathrm{km}{ }^{2}\right)\end{array}$ & $25-29$ & 8-9 & 33-38 \\
\hline $1865-1944$ & 25 & 8 & 33 \\
\hline 1945-1996 & 29 & 9 & 38 \\
\hline $\begin{array}{l}\text { Subsidence area until } 1996 \text { (in km²) } \\
\text { Osiadanie powierzchni do } 1996 \text { r. }\left(\mathrm{w} \mathrm{km}^{2}\right)\end{array}$ & 29 & 7 & 36 \\
\hline $1865-1944$ & 16 & 5 & 21 \\
\hline 1945-1996 & 13 & 2 & 15 \\
\hline $\begin{array}{l}\text { Volume of subsidence until } 1996 \\
\text { (in million m³) } \\
\text { Objętość osiadania do } 1996 \text { r. (w mln m³) }\end{array}$ & 192.1 & 23.7 & 215.8 \\
\hline $1865-1944$ & 133 & 10,0 & 143 \\
\hline 1945-1996 & 59.1 & 13.7 & 72.8 \\
\hline $\begin{array}{l}\text { Average depression of an area } \\
\text { until } 1996 \text { (in m) } \\
\text { Średnie obniżenie powierzchni terenu } \\
\text { do } 1996 \mathrm{r} \text {. }\end{array}$ & 12.8 & 4.4 & 6.0 \\
\hline $1865-1944$ & 8.3 & 2.0 & 6.8 \\
\hline $1945-1996$ & 4,5 & 2,4 & 3,9 \\
\hline $\begin{array}{l}\text { Anthropogenic denudation until } 1996 \\
\text { (in mm/year) } \\
\text { Denudacja antropogeniczna } \\
\text { do } 1996 \mathrm{r} \text {. (w mm/r.) }\end{array}$ & 96 & 36 & 66 \\
\hline $1865-1944$ & 115 & 35 & 75 \\
\hline 1945-1996 & 77 & 36 & 57 \\
\hline
\end{tabular}

Basin the size of the depression was almost three times bigger than in the Kuźnice Basin (12.8 $\mathrm{m}$ and $4.4 \mathrm{~m}$ ). During the period 1865-1944 the surface of the terrain was lowered, on average by $6.8 \mathrm{~m}$, while in the years 1945-1996 additionally by $3.9 \mathrm{~m}$. In the years 1865-1944 the average value of ground depression in the Wałbrzych Basin was higher than in the later period - 1945-1996 (8.3 m and $4.5 \mathrm{~m}$ ), while in the Kuźnice Basin there were similar values of subsidence $(2.0 \mathrm{~m}$ and $2.4 \mathrm{~m}$ ). The scale of anthropogenic denudation, determined based on the amount of excavated coal and gangue, was diverse in the research area. The average pace of that process for the Wałbrzych coal mining area during the analyzed period amounted to $66 \mathrm{~mm} /$ year; in the years 1865-1944 it was faster than in the following period -1945-1996 (75 mm/year and $57 \mathrm{~mm} /$ year). The intensity of anthropogenic 
denudation in the aforementioned processes in the Wałbrzych Basin decreased from $115 \mathrm{~mm} /$ year to $77 \mathrm{~mm} /$ year, while in the Kuźnice Basin it increased from $35 \mathrm{~mm} /$ year to $36 \mathrm{~mm} /$ year.

The spatial diversity of the scale of anthropogenic denudation in the Wałbrzych coal mining area was also determined based on the results of precise geodetic measurements conducted there since 1912. It needs to be emphasized that there was a considerably higher number of precise leveling benchmarks in the Wałbrzych Basin (28) than in the Kuźnice Basin (3). As a result, we currently possess more data concerning anthropogenic denudation in the Wałbrzych area. It was also determined that the size of anthropogenic denudation was diverse in the Wałbrzych Basin: 5-341 mm/year. A considerable intensity of the process (over $100 \mathrm{~mm} / \mathrm{year}$ ) was connected with areas where the industrial coal excavation started as early as in the second half of the 19th century; those areas include the north-western and western part of the Wałbrzych Basin - Biały Kamień (Wałbrzych) (224 mm/ year) Sobięcin $(314 \mathrm{~mm} /$ year $)$ and the downtown of Wałbrzych $(322 \mathrm{~mm} / \mathrm{year})$. In the southern part of the Wałbrzych Basin considerable sizes of anthropogenic
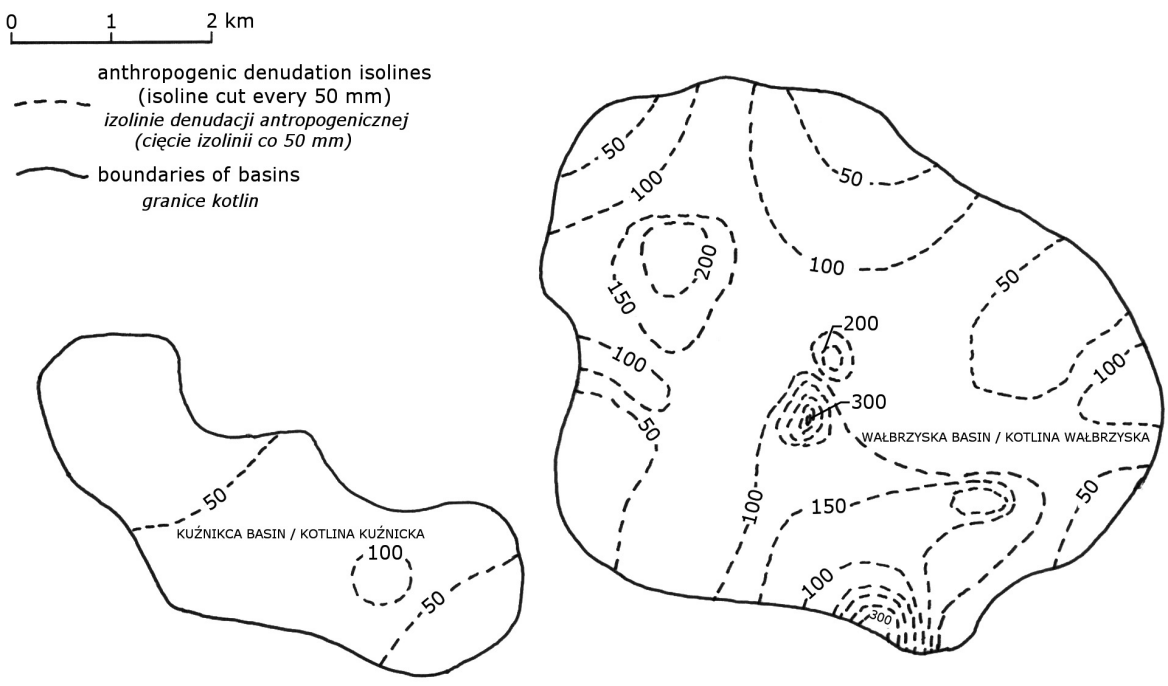

Fig. 5. Average annual intensity of anthropogenic denudation in the Wałbrzych Basin calculated basing on the results of geodetic measurements of land subsidence in between 1912-1996 Ryc. 5. Średnie roczne natężenie denudacji antropogenicznej w Zagłębiu Wałbrzyskim obliczone na podstawie wyników pomiarów geodezyjnych z lat 1912-1996 
denudation (112-341 mm/year) are connected with coal exploitation after 1960 in Wałbrzych Podgórze. The mining areas where anthropogenic denudation exceeded $100 \mathrm{~mm} /$ year were those areas where coal exploitation was carried out mainly using the caving method. In the eastern and south-eastern parts of Wałbrzych the dynamics of this process was much lower and did not exceed $100 \mathrm{~mm} /$ year.

The intensity of anthropogenic denudation in the Kuźnice Basin, calculated based on the results of geodetic measurements of land subsidence, was considerably smaller than in the Wałbrzych Basin (34-101 mm/year). The process proceeded slightly faster in the south-east than in the north-west part of the aforementioned basin, which results from the intensive coal exploitation in Kuźnice Świdnickie. Among the vital factors influencing the small degree of subsidence and anthropogenic denudation in the Kuźnice Basin we can distinguish: concentration of coal excavation in the sides of Gorców coal basin, beginning of intensive coal exploitation only after the year 1950, as well as a sixfold smaller excavation of this raw material than in Wałbrzych (Fig. 5).

Based on the morphometric analysis, it was determined that in the years 1884-1996 the area of the Wałbrzych coal mining area influenced by mining was lowered by 1-14 m. In the Wałbrzych Basin the subsidence amounted to 3-14 m, while in the Kuźnice Basin to 1-3 m (Tab. 4). Those findings are similar to data obtained based on geodetic measurements. However, it was impossible to obtain more precise data due to different scales of the maps, generalizations of contour maps and interpolation of estimation of the height of certain locations. The pace of anthropogenic denudation was diversified (9-125 mm/year); in the Wałbrzych Basin the intensity of this process amounted to 27-125 mm/year, while in the Kuźnice Basin it was 9-27 mm/year. The average pace of anthropogenic denudation in the Wałbrzych coal mining area determined based on the morphometric analysis is slower than that calculated while taking into consideration the excavation of coal and gangue. Those discrepancies result from different periods for which the scale of anthropogenic denudation was determined (1865-1996 and 1884-1996), as well as different data obtained using various methods used to calculate the intensity of this process.

Considering the scale of area subsidence and dynamics of anthropogenic denudation in the Wałbrzych coal mining area it needs to be emphasized that its territory is located in the zone of neotectonic movements of the Sudetes block. The rock mass upthrust in the analyzed region is minor, as it amounts to 1-4 mm/year (Kowalczyk 1969; Rejman 1982; Pinińska 1993; Krzyszkowski et al. 1995, 1998). It is difficult to differentiate the results of subsidence caused by anthropopressure and upthrust related to neotectonics. It was assumed that the slow pace of neotectnotic movements did not considerably influence the scale of subsidence and anthropogenic denudation in the research area.

Big dumps located in Wałbrzych cover the area from 20 ha to 50 ha, have a height of from $60 \mathrm{~m}$ to $105 \mathrm{~m}$ and the volume of between 9 million $\mathrm{m}^{3}$ to 23 million $\mathrm{m}^{3}$. 
Table 4. Land subsidence and anthropogenic denudation intensity in the Wałbrzych Basin basing on the morphometric analysis of topographic maps from 1884, 1925, 1939, 1976 and 1996 Tab. 4. Osiadanie powierzchni terenu oraz natężenie denudacji antropogenicznej na podstawie analizy morfometrycznej map topograficznych z lat: 1884, 1925, 1939, 1976 i 1996

\begin{tabular}{|l|c|c|c|}
\hline \multirow{2}{*}{$\begin{array}{c}\text { Specification } \\
\text { Wyszczególnienie }\end{array}$} & \multirow{2}{*}{$\begin{array}{c}\text { Rock mass subsiding (in m) } \\
\text { Osiadanie górotworu (w m) }\end{array}$} & \multicolumn{2}{|c|}{$\begin{array}{c}\text { Anthropogenic denudation (in mm/year) } \\
\text { Denudacja antropogeniczna (w mm/r.) }\end{array}$} \\
\cline { 3 - 4 } & $\begin{array}{c}\text { diversification } \\
\text { zróżnicowanie }\end{array}$ & $\begin{array}{c}\text { average } \\
\text { średnia }\end{array}$ \\
\hline $\begin{array}{l}\text { Wałbrzych coal mining area } \\
\text { Zagłębie Wałbrzyskie }\end{array}$ & $1-14$ & $9-125$ & 67 \\
\hline $\begin{array}{l}\text { Wałbrzych Basin } \\
\text { Kotlina Wałbrzyska }\end{array}$ & $3-14$ & $27-125$ & 76 \\
\hline $\begin{array}{l}\text { Kuźnicka Basin } \\
\text { Kotlina Kuźnicka }\end{array}$ & $1-3$ & $9-27$ & 18 \\
\hline
\end{tabular}

It is estimated that they store from 24 million to 61 million tons of accumulated mining waste. Consequently, those forms significantly influence the substrate causing deformation of the ground. In the foreground of one of Wałbrzych dump it was observed that there are noticeable deformations of the ground (undulations) with a height of $1 \mathrm{~m}$ and length of $20 \mathrm{~m}$. Similar forms are located in the coal mining areas of Upper Silesa in Poland and Ostrava-Karvina in the Czech Republic (Klęczar 1952; Dulias 2013). In the Wałbrzych coal mining area no research concerning substrate deformation caused by dumps has been conducted.

The scant information concerning the influence of vibrations caused by rail traffic on the subsidence of terrain in Wałbrzych is included in the report entitled Mining Areas Conservation Programme (1985). However, the information is not supported by any research.

Certain discrepancies were noticed when comparing the intensity of anthropogenic denudation determined based on coal and gangue excavation with the pace of that process calculated using the results of geodetic measurements. Based on the results of geodetic measurements it was determined that the average rate of anthropogenic denudation in the Wałbrzych Basin amounted to $115 \mathrm{~mm} / \mathrm{year}$, while for the Kuźnice Basin to $73 \mathrm{~mm} /$ year. Assuming that the basis of calculation is the amount of excavated coal and gangue, it was determined that anthropogenic denudation in the Wałbrzych Basin amounted 96 mm/year and in the Kuźnice Basin 36 mm/year. Small differences between obtained values concerned the Wałbrzych Basin rather than the Kuźnice Basin, which is connected with a more developed subsidence measuring network and a longer period of regular measurements conducted in the Wałbrzych Basin in comparison with the Kuźnice Basin. In the first of the aforementioned areas there were 28 , while in the second only 3 precise levelling points. What 
is more, in the Wałbrzych Basin regular measurements of subsidence were conducted since 1912, while in the Kuźnice Basin only since 1955 (Program ochrony... 1985; Pinińska 1993; Wójcik 2011). The Kuźnice Basin is also an area where an intensive coal exploitation began later (after 1950), and the excavation of this raw material was considerably smaller than in the Wałbrzych Basin. The abovementioned facts serve as an explanation of differences between the values of intensity of anthropogenic denudation in both basins obtained using different methods.

When comparing the pace of anthropogenic aggradation and anthropogenic denudation and their geomorphic consequences it needs to be emphasized that the first of the aforementioned processes was more dynamic. In the years 1865-1996 the average annual pace of anthropogenic aggradation in the Wałbrzych coal mining area amounted to $328 \mathrm{~mm}$, while the intensity of anthropogenic denudation was five times lower $(66 \mathrm{~mm} / \mathrm{year})$. The disproportions in the dynamics of the analyzed processes were notably smaller in the Wałbrzych Basin than in the Kuźnice Basin $(307 \mathrm{~mm} /$ year and $96 \mathrm{~mm} /$ year; $455 \mathrm{~mm} /$ year and $36 \mathrm{~mm} / \mathrm{year}$ ). The pace of the anthropogenic aggradation in both basins in the years 1945-1996 increased in comparison to the earlier period - 1865-1944. During the aforementioned periods, the intensity of anthropogenic denudation increased slightly only in the Kuźnice Basin, while in the Wałbrzych Basin a decline of the pace this process was noticed. Additionally, a more considerable spatial differentiation of intensity of the analyzed processes was noted in the Wałbrzych than Kuźnice Basin. In the first of the aforementioned areas anthropogenic aggradation and denudation ranged from 217-1818 mm/year and 5-341 mm/year, while in the second from 315-914 mm/year and $34-101 \mathrm{~mm} /$ year.

A characteristic feature of anthropogenic denudation in the Wałbrzych coal mining area in the period 1865-1996 was a positive denudation balance (Tab. 5), which was significantly diverse both in time and space: for the Kuźnice Basin it amounted to $+419 \mathrm{~mm} /$ year, while for the Wałbrzych Basin $+211 \mathrm{~mm} / \mathrm{year}$. The rate of denudation balance in the years 1945-1996, when compared with the period of 1865-1944, increased considerably from $180 \mathrm{~mm} /$ year to $382 \mathrm{~mm} / \mathrm{year}$. This trend was characteristic for both basins (Tab. 5).

The intensity of anthropogenic aggradation and denudation during the last 130 years of mining in the Wałbrzych coal mining area notably exceeded the dynamics of natural aggradation and denudation. According to Jońca (1979, 1985) the vertical growth of sediments in the Pełcznica Valley (Wałbrzych Basin) since the beginning of the 20th century amounted to, on average, $10 \mathrm{~mm} / \mathrm{year}$. A layer of sediments with a thickness of $1 \mathrm{~m}$ consists of coal duff from settling ponds. Numerous places in the Pełcznica Valley are places of "coal trail” (Jońca 1960; Wójcik 2011). In the Lesk Valley (Kuźnice Basin ) the pace of natural aggradation amounted to $7 \mathrm{~mm}$ /year (Program ochrony... 1985). In the Kuźnice Basin anthropogenic aggra- 
Table 5. Denudation balance of the Wałbrzych Basin area for the period of 1865-1996 based on coal and gangue extraction

Tab. 5. Bilans denudacyjny Zagłębia Wałbrzyskiego dla okresu 1865-1996 na podstawie wydobycia węgla i skał płonnych

\begin{tabular}{|c|c|c|c|}
\hline $\begin{array}{c}\text { Specification } \\
\text { Wyszczególnienie }\end{array}$ & $\begin{array}{c}\text { Anthropogenic denudation } \\
\text { (in mm/year) } \\
\text { Denudacja antropogeniczna } \\
\text { (w mm/r.) }\end{array}$ & $\begin{array}{c}\text { Anthropogenic aggradation } \\
\text { (in mm/year) } \\
\text { Agradacja antropogeniczna } \\
\text { (w mm/r.) }\end{array}$ & $\begin{array}{c}\text { Denudation balance } \\
\text { (in mm/year) } \\
\text { Bilans denudacyjny } \\
\text { (w mm/r.) }\end{array}$ \\
\hline $\begin{array}{l}\text { Wałbrzych coal mining area } \\
\text { (until 1996) } \\
\text { Zagłębie Wałbrzyskie } \\
\text { (do } 1996 \text { r.) }\end{array}$ & 66 & 328 & +262 \\
\hline $1865-1944$ & 75 & 255 & +180 \\
\hline $1945-1996$ & 57 & 439 & +382 \\
\hline $\begin{array}{l}\text { Wałbrzych Basin } \\
\text { (until 1996) } \\
\text { Kotlina Wałbrzyska } \\
\text { (do } 1996 \text { r.) }\end{array}$ & 96 & 307 & +211 \\
\hline $1865-1944$ & 115 & 236 & +121 \\
\hline $1945-1996$ & 77 & 416 & +339 \\
\hline $\begin{array}{l}\text { Kuźnicka Basin (until 1996) } \\
\text { Kotlina Kuźnicka } \\
\text { (do } 1996 \text { r.) }\end{array}$ & 36 & 455 & +419 \\
\hline 1865-1944 & 35 & 361 & +326 \\
\hline $1945-1996$ & 36 & 598 & +562 \\
\hline
\end{tabular}

dation proceeded 65 times faster and in the Wałbrzych Basin and 34 times faster than natural aggradation.

The relief of the analyzed area is a group of natural and anthropogenic forms. Natural terrain elevations located in the basins are mostly bigger than the neighboring dumps. In the result of rock mass subsidence related to anthropopressure, the natural surface of terrain was lowered by at least $18 \mathrm{~m}$. The last 130 years of development of mining was the time of the height difference increase by $150 \mathrm{~m}$ in the Wałbrzych Basin and by $65 \mathrm{~m}$ in the Kuźnice Basin. The differences in height within the anthropogenic relief of the Wałbrzych Basin are almost twice as big as within the natural relief in this subsidence $(150 \mathrm{~m}$ and $80 \mathrm{~m})$ and similar in the Kuźnice Basin (72 $\mathrm{m}$ and $65 \mathrm{~m}$ ).

As a result of mining, flat surfaces and terrain elevations located in the bottoms of basins underwent the process of undulation and subsidence; certain depressions were filled with mining waste used to create dumps. Formerly flat surfaces were transformed into depressions or elevations. In numerous locations the natural relief disappeared and was replaced by anthropogenic forms. Intensive anth- 
ropopression lasting for 130 years led to the emergence of anthropogenic relief inversion, a process defined by the author as such a terrain transformation which led to creation of elevations in natural dips, and dips in flat and slightly convex areas (Wójcik 1993, 2011).

When assessing the visual aspect of the anthropogenic relief, as opposed to the natural relief of the Wałbrzych coal mining area, it needs to be emphasized that visible results of anthropogenic aggradation are more distinct than those of anthropogenic denudation. Dumps are the dominant elements of landscape as they constitute the dynamics of the relief. Subsidence depressions cover considerable areas, nevertheless they are not very deep. That is why those forms are difficult to be noticed, even in the subtly diverse relief of the bottom of the basin. What is more, they easily interconnect without a clearly marked border between natural depressions. Subsidence depressions did not vitally influence the physiognomy of the analyzed area relief.

\section{Discussion}

When compared to the coal mining areas of Upper Silesia, Ostrava-Karvina and Ruhr, the Wałbrzych coal mining area covers a small area $(95 \mathrm{~km} 2)$. What is more, it is located in the mountains (Sudetes). The average intensity of anthropogenic aggradation in the Wałbrzych coal mining area in the years 1865-1996 amounted to $328 \mathrm{~mm} /$ year. There was a considerable regional differentiation in the dynamics of that process: from 315-914 mm/year in the Kuźnice Basin, up to 333-1818 mm/year in the Wałbrzych Basin. In the Upper Silesian coal mining area, the pace of anthropogenic aggradation, established based on the morphometric analysis, amounted to $1-9 \mathrm{~mm} / \mathrm{year}$. The anthropogenic aggradation rate for selected dumps in the aforementioned basin was considerably higher, as it amounted to $80-1258 \mathrm{~mm} /$ year (Wojciechowski 2007; Dulias 2013). It also needs to be emphasized that the pace of the analyzed process was faster in the Wałbrzych coal mining area in comparison with other mining areas. This phenomenon can be a result of the small area of the Wałbrzych coal mining area $\left(95 \mathrm{~km}^{2}\right)$ in comparison with the size of the Upper Silesia coal mining area $\left(5,600 \mathrm{~km}^{2}\right)$, mountainous terrain limiting the development of dumps, a high rate of coal mining generated waste (1.6 ton of gangue for 1 ton of coal), as well as the storage of large amount of waste on the ground surface (Czocher et al. 1978; Wójcik 1993, 2011).

The intensity of anthropogenic aggradation in the Ostrava-Karvina region (the Czech Republic) in the 20th century on average amounted to $440 \mathrm{~mm} / \mathrm{year}$ (Dulias 2013). The analyzed process underwent there faster than in the Wałbrzych coal mining area, because of, among others, a sixfold bigger amount of extracted coal and, related to it, considerable amounts of gangue (1.1-1.8 ton of waste for 
1 ton of coal), as well as the fact that $35 \%$ of waste was stored on dumps (Scheibalova 2003; Dulias 2013).

One of the biggest areas of coal mining in Europe is the Ruhr (Ruhrgebiet), where, as early as in 1939 and in the middle of 1950s, approximately 130 million tons of coal was extracted per year. Later the extraction systematically decreased and, in 1997, it reached the value of 35 million tons (Petsch 1982; Sroka 1999). In the years 1960-1980, the amount of gangue per 1 ton of coal increased from 057 ton to 0.9 ton (Petsch 1982). According to Bell et al. (2000), 2-2.5 billion m ${ }^{3}$ of gangue was extracted in the Ruhr, of which $70 \%$ was transported to dumps. Those forms cover an area of $26.6 \mathrm{~km}^{2}$. According to Harnischmacher (after Dulias 2013, 2016 ), in one of the areas in the Ruhr , covering an area of $28.8 \mathrm{~km}^{2}$, the volume of stored mining waste amounts to 80 million $\mathrm{m}^{3}$. The ground level elevated there on average by $2.8 \mathrm{~m}$, in a pace of $29 \mathrm{~mm}$ /year. In comparison with the Wałbrzych coal mining area $(328 \mathrm{~mm} / \mathrm{year})$, the pace of anthropogenic aggradation there is 11 times slower.

The average intensity of anthropogenic denudation in the Wałbrzych coal mining area Basin in the years 1865-1996 amounted to $66 \mathrm{~mm} / \mathrm{year}$ and was higher than in the Ostrava-Karvina mining area $(47 \mathrm{~mm} /$ year $)$. Nevertheless, the diversification of the pace of this process in various places located in the aforementioned mining areas was more substantial in the Ostrava-Karvina region than in the Wałbrzych coal mining area (28-136 mm/year and 36-96 mm/year).

In the years 1883-1993, the average rate of anthropogenic denudation in the Upper Silesia mining area $(21 \mathrm{~mm} /$ year) was considerably slower than in the Wałbrzych coal mining area $(66 \mathrm{~mm} / \mathrm{year})$. However, the diversification of the analyzed value for the selected mining areas in the Upper Silesia (4-156 mm/year) was higher than in the Wałbrzych coal mining area (25-115 mm/year) (Dulias 2013).

In the Ruhr the average value of anthropogenic denudation in the previous century amounted to $15 \mathrm{~mm} /$ year (Dulias 2013) and was four times lower than in the Wałbrzych coal mining area. Also, the spatial diversification of that process was lower in the first of the aforementioned basins (5-40 mm/year and 25-115 mm/year).

A characteristic trait of anthropogenic denudation in the Wałbrzych coal mining area during the last 130 years of coal extraction is a positive denudation balance (on average $+262 \mathrm{~mm} /$ year); as a comparison, the denudation balance in the Upper Silesia in the aspect of mining anthropopressure was negative in the years 1883-1993 (-13 mm/year) (Dulias 2013).

The author's research, as well as data included in the cited publications indicate that the average intensity of anthropogenic denudation in coal mining areas was diverse and ranged from a dozen or so to several dozen of $\mathrm{mm} / \mathrm{year}$ and, locally, even to a hundred and several dozen $\mathrm{mm} / \mathrm{year}$. The pace of natural denudation in the mountain areas is by far slower than the intensity of anthropogenic denudation 
(Dulias 2013). That is why, the claims of the precursors of the research in this field, Marsh (1864), Fischer (1915) and Scherlock (1923), that, even as early as in the $19^{\text {th }}$ century, human activity was the main factor of relief change in mining areas, i.a. in Great Britain and Germany, are fully justified.

\section{Conclusion}

The Wałbrzych coal mining area is located in two minor Sudetes basins: Wałbrzych and Kuźnice. During the last 130 years of coal mining activity, a complex of anthropogenic relief consisting of dumps, settling ponds and subsidence depressions emerged in this area. Among the crucial geomorphological processes related to coal mining taking place in the analyzed area there were: anthropogenic aggradation and anthropogenic denudation. The result of the first of the aforementioned processes was the terrain elevation, while the other resulted in lowering of the ground surface. The elevation of the terrain took place in the area of $4.26 \mathrm{~km}^{2}$, where the anthropogenic strata with a volume of 93.5 million $\mathrm{m}^{3}$ was stored. Rock mass subsidence occurred on the area of $36 \mathrm{~km}^{2}$ and the total volume of the decline amounted to 215.8 million $\mathrm{m}^{3}$. The average pace of anthropogenic aggradation amounted to $328 \mathrm{~mm} /$ year and was considerably diverse in time (1865-1944: $255 \mathrm{~mm} / \mathrm{year}$, 1945-1996: $439 \mathrm{~mm} / \mathrm{year}$ ) and space (the Wałbrzych Basin: 236-416 mm/year, the Kuźnice Basin: 361-598 mm/year). The average intensity of anthropogenic denudation amounted to $66 \mathrm{~mm} / \mathrm{year}$, and it also varied in time (1865-1944: $75 \mathrm{~mm} / \mathrm{year}$, 1945-1996: $57 \mathrm{~mm} /$ year) and space (the Wałbrzych Basin: 77-115 mm/year, the Kuźnice Basin: 35-36 mm/year). In comparison with other mining areas in Poland and Europe, the average pace of anthropogenic aggradation in the Wałbrzych coal mining area was significantly faster than in the big mining areas of the Upper Silesia and the Ruhr, while slower than in the Ostrava-Karvina region, which resulted from, among others, the substantial amount of gangue for each ton of extracted coal and the considerable amount of waste stored on dumps. The intensity of anthropogenic denudation in the aforementioned areas was also diverse, as the average pace of this process in the past century was highest in the Wałbrzych coal mining area (66 mm/year), while in the Upper Silesia it was three times lower (21 mm/year), in the Ruhr four times lower (16 mm/year) and in the Ostrava-Karvina region lower by approximately $30 \%$ (47 mm/year). It needs to be emphasized that the intensity of anthropogenic denudation at a local scale was more diverse than it is suggested by the averaged above data. In numerous parts of the Wałbrzych coal mining area the intensity of anthropogenic denudation was considerable $(341 \mathrm{~mm} / \mathrm{year})$ and mostly higher than in other coal mining areas. In the years 1865-1996 the intensity of anthropogenic aggradation significantly exceeded the pace of anthropogenic 
denudation. What is specific about the anthropogenic denudation process in the research area is a positive denudation balance (on average $+262 \mathrm{~mm} /$ year); as a comparison, in the Upper Silesia in the years 1883-1993 the denudation balance was negative (on average $-13 \mathrm{~mm} /$ year). A result of the influence of aforementioned processes is the emergence in the Wałbrzych coal mining area of the anthropogenic relief with bigger height differences $(150 \mathrm{~m})$ than those occurring within the natural relief $(80 \mathrm{~m})$.

\section{References}

Bell F.G., Stacey T.R., Genske D.D., 2000, Mining subsidence and its effect on the environment some differing examples, Environmental Geology, 40, 135-152.

Borecki M., 1980, Ochrona powierzchni præed sækodami górniczymi, Wydawnictwo Śląsk, Katowice.

Corbel J., 1959, Erosion en terrain calcaire, Annales de Géographie, 336, 97-120.

Corbel J., 1968, Erowja na powieræchni ziemi. Studium ilościowe, Przegląd Zagranicznej Literatury Geograficznej, 23, 147-180.

Czocher R., Kawczak S., Pisanecka K., 1978, Pięć wieków węgla kamiennego na Dolnym Ślqsku, Stowarzyszenie Inżynierów i Techników Górnictwa, Wałbrzych.

Demek J., 1973, Uvod do studia reliefu Zemle, (typescript), SPN, Praha.

Douglas I., Lavson N., 2001, Materials flows for mining and quarrying, [in:] T. Munn (ed.), Encyclopedia of Global Environmental Change, 3, 454-461.

Dulias R., 2011, Impact of mining subsidence on the relief of the Rybnik Plateau, Poland, Zeitschrift für Geomorphologie, 55, Suppl., 1, 25-36.

Dulias R., 2013, Denudacja antropogeniczna na obszarach górniczych na przyktadzie Górnoślaskiego Zagtęia Weglowego, Uniwersytet Śląski, Katowice.

Dulias R., 2016, The Impact of Mining on the Landscape: A Study of the Upper Silesian Coal Basin in Poland, Springer, 209.

Dylik J., 1954, Problematyka geomorfologiczna wobec potrzeb rolnictwa, Przegląd Geograficzny, 26, 4-36.

Dylik J., 1958, Istota i metody geomorfologii dynamicznej, Acta Geographica Lodziensis, 8, 23-66.

England P., Molnar P., 1990, Surface uplift, uplift of rocks and exchumations od rocks, Geology, $18,1173-1177$.

Fischer E., 1915, Der Mensch als Geologischer Factor, Zeitschrift der Deutschen Geologischen Gesellschaft, 67, 106-148.

Goudie A.S., 1995, The changing Earth Rates of Geomorphological Processes, Blackwell, Oxford. Goudie A.S., Viles H., 1997, The Earth Transformed, Blackwel, Oxford.

Graf R., Kaniecki A., Medyńska-Gulij B., 2008, Dawne mapy jako zródto informacji o wodach śódladowych i stopniu ich antropogenic nych przeksঞtatceń, Badania Fizjograficzne nad Polską Zachodnią, ser. A: Geografia fizyczna, 59, 11-27. 
Gregory J.W., 1911, The terms "denudation", "erosion”, "corrosion" and "corrasion", The Geographical Journal, 37, 189-195.

Hooke R., 1999, Spatial distribution of human geomorphic activity in the United States: comparison with rivers, Earth Surface Processes Landforms, 24, 687-692.

Jahn A., 1968, Selektywna erozja gleb i jej znaczenie w badaniach geomorfologicznych, Przegląd Geograficzny, 40, 419-424.

Jania J., 1983, Antropogeniczne zmiany rzę́by terenu weschodniej części Wyżyny Śląsiej, Prace Naukowe Uniwersytetu Śląskiego, 575, 69-91.

Jaros J., 1975, Zarys dziejów górnictwa węgla, PWN, Warszawa-Kraków.

Jońca E., 1960, Terasa weglowa Ogoræelca, Wszechświat, 2, 53-54.

Jońca E., 1979, Środowisko geograficæno-przyrodnicæe miasta Watbræycha, Kronika Wałbrzyska, 2, 59-82.

Jońca E., 1985, Geograficะno-przyrodniče warunki rowwoju $i$ \&agadnienie ochrony środowiska miasta Watbrzycha, Przegląd Geograficzny, 7, 73-89.

Jońca E., Kacperkiewicz L., 1986, Wybrane problemy ochrony środowiska Watbrzycha, Kronika Wałbrzyska, 5, 5-41.

Klęczar, T., 1952, Szkody górnicze, PWT, Katowice.

Klimaszewski M., 1978, Geomorfologia, PWN, Warszawa.

Kowalczyk Z., 1969, Wspótcæesne ruchy tektonicæne na terytorium Ślqska w świetle badań geodezyjnych, Zeszyty Naukowe AGH - Geodezja, 212, 121-145.

Krzyszkowski D., Migoń P., Sroka W., 1995, Neotetconic Quaternary history of the Sudetic Marginal Fault, SW Poland, Folia Quaternaria, 66, 73-98.

Krzyszkowski D., Stachura R., 1998, Late Quaternary valley formation and neotectonic evolution on the Watbryych Upland, Middle Sudetem Mts., Annales Societatis Geologorum Poloniae, 68, 23-60.

Kupka R., Szczypek T., Wach J., 2005, Morphological effect of 200-years long hard coal exploitation in Katowice, [in:] J. Szabo, R. Morkunaite (ed.), Landscapes-nature and man, University of Debrecen and Lithuanian Institute of Geology and Geography, Debrecen-Vilnius, 95-100.

Lach I., 1984, Geomorfologiczne skutki antropopresji rolniczej na wybranych cześciach Karpat i ich Præedgórza, Prace Monograficzne 66, WSP, Kraków.

Luksa J., 1959, Rozwój wydobycia w kopalniach wegla kamiennego w Polsce w latach 1769-1948, Studia i materiały PTE, Katowice, 3-70.

Mannion A.M., 1997, Global Environmental Change: A Natural and Cultural Environmental History, Addison Vesley Longman Limited.

Marsch G.P., 1864, Man and Nature, The Belknap Press of Harvard University Press, Cambridge, Massachusetts (Second Printing).

Ohle K., 1927, Der Kreis Waldenburg in Niederschlesischen Industriegebiet in Vergangenheit und Gegenvart, Breslau.

Petsch G., 1982, Environmental problems of coal production in the Federal Republic of Germany with particular reference to the Ruhr, Minerals and the Environment, 4, 75-80. 
Pflug K., 1908, Chronik der Stadt Waldenburg in Schlesien, Waldenburg.

Piątek Z., 1995, Górnictwo węgla kamiennego na Dolnym Ślasku (1434-1945-1994), Przegląd Górniczy, 1, 25-29.

Pinińska J., 1993, Retrospektywna ocena geologicæno-inżynierska deformacji powierzchni terenu Watbrzycha, Przegląd Geologiczny, 3, 193-199.

Podgórski Z., 2001, Antropogeniczne zmiany rzezby terenu na obsæarze Polski, Przegląd Geograficzny, 73, 37-56.

Price S.J., Ford J.R., Cooper A.H., Neal C., 2011, Humans as major geological and geomorphological agents in the Anthropcene: the significance of artificial ground in Great Britain, Philosophical Transactions of The Royal Society, 369, 1056-1084.

Program ochrony terenów górniczych KWK Thorez, Victoria $i$ Watbrzych na lata 1986-2010, 1985 (maszynopis), Dolnośląskie Gwarectwo Węglowe, Wałbrzych.

Pulina M., 1974, Denudacja chemic na na obsæarach krasu weglanowego, Prace Geograficzne IG PAN, 105, 55-99.

Rejman J., 1982, Interpretacja pionowych przemieszcen reperów watbrzyskiej sieci niwelacji precyzyjnej, Ochrona Terenów Górniczych, 61, 27-30.

Sheen S.W., 2000, A Word Model of Chemical Denudation in Karst Terrains, The Professional Geographer, 52, 397-406.

Sherlock R.L., 1923, The influence of man as agent in geographical change, Geographical Journal, 61, 258-273.

Sinkiewicz M., 1998, Rozwój denudacji antropogenicznej w środkowej części Polski Pótnocnej, (maszynopis), Uniwersytet Mikołaja Kopernika, Toruń.

Smolska E., 2005, Znaczenie sptukiwania w modelowaniu stoków mtodoglacjalnych (na przykładzie Pojezier:a Suwalskiego), (maszynopis), Uniwersytet Warszawski, Warszawa.

Solarski M., Pradela A., 2010, Przemiany wybranych form rzeźby Wyżyny Miechowskiej w latach 1883-1994, [in] R. Machowski, M.A. Rzętała (ed.) Z badań nad wptywem antropopresji na środowisko, 11, 78-92.

Spencer W., 1983, Physical Geology, Addison-Wesley Publ. Company, Masaachusetts.

Sroka A., 1999, Dynamika eksploatacji górniczej z punktu widzenia sækód górniczych, Studia, Rozprawy, Monografie, 58, Instytut Gospodarki Surowcami Mineralnymi PAN, Kraków.

Szczypek T., Trembaczowski J., 1987, Wyrobiska po eksploatacji surowców mineralnych w środkowej części Wy:̈yny Krakowsko-Wieluńskiej, Geographia. Studia et Dissertationes, 10, 100-112.

Tricart J., 1960, Zagadnienia geomorfologic:ne, PWN, Warszawa.

Walling D.E., 2006, Tracing versus monitoring: New challenges and opportunities in erosion and sediment delivery research, Soil Erosion and Sediment Redistribution in River Catchments, CABI. Wallingford, UK, 13-27.

Wilkinson B.H., Mc Elroy B.J., 2007, The impact of humans on continental erosion and sedimentation, GSA Bulletin, 119, 140-156.

Wojciechowski T., 2007, Osiadanie powier «chni siemi pod wptywem eksploatacji wegla kamiennego 
na przyktadzie rejonu miasta Knurowa, Przegląd Geologiczny, 55, 589-594.

Wójcik J., 1993, Przeobrażenia uksztattowania powierzchni ziemi pod wptywem górnictwa w rejonie Watbrzycha, Acta Universitatis Wratislaviensis, 1557, Studia Geograficzne, 59, 5-145.

Wójcik J., 1996, Præeks«tatcenia ræeźby powstatej pod wptywem górnictwa weglowego w Watbrzychu i okolicy, 1865-1990, Przegląd Geograficzny, 68 (1-2), 181-191.

Wójcik J., 2011, Przemiany wybranych komponentów środowiska przyrodničego rejonu watbrzyskiego w latach 1975-2000, w warunkach antropopresji, ze szczególnym uwzględnieniem wptywu przemystu, Rozprawy Naukowe Instytutu Geografii i Rozwoju Regionalnego Uniwersytetu Wrocławskiego, 21, 5-469.

Wójcik J., 2013, Mining changes on the example of the Watbrzych Basin relief (The Sudetes, Poland), Zeitschrift für Geomorphologie, 57 (2), 187-205.

Zapletal L., 1968, Genetic-Morphologic classification of anthropogenic relief features, Acta Universitatis Palackinae Olomunicesis, Fac. Rerum Natur., 23, Geogr. - Geol. VIII, 239-427.

Zapletal L., 1969, Uvod do antropogenni geomorfologie, Universitat Palackinae v Olomouci, Olomouc.

Żmuda S., 1973, Antropogeniczne præeobrażenia środowiska przyrodniczego konurbacji górnoślaskiej, PWN, Warszawa-Kraków.

Jan Wójcik

Institute of Geography and Regional Development

Uniwersytecki Square 1

50-137 Wroctaw, Poland

jw57@o2.pl 
